\title{
Research on the Innovation of Teaching Method and the Cultivation of Innovative Undertaking Talents in Colleges
}

\author{
Renbo $\mathrm{Xu}^{1,2, \mathrm{a}^{*}}$, Jinfeng $\mathrm{Li}^{1, \mathrm{~b}}$ and Youhui Zou ${ }^{1, \mathrm{c}}$ \\ ${ }^{1}$ School of electrical and information Engineering, Nanchang Institute of Science and Technology \\ Nanchang, 330108, china. \\ ${ }^{2}$ Physics and Microelectronics Institute, Central South University Changsha 410083 china. \\ aCorresponding author: 1310079831@qq.com \\ b524892454@qq.com \\ c1453939839@qq.com
}

Keywords: Teaching methods innovation; Innovative undertaking talents; Open practice teaching; Research and countermeasures

\begin{abstract}
Innovation of teaching method is the inevitable requirement for cultivating innovative undertaking talents. It is the inevitable choice to innovate the teaching method of colleges on the basis of perfect lecture teaching, focusing on open practice education, taking independent research based learning as the core, and establishing an open and diverse teaching method system. This paper makes an in-depth study on the relationship between the innovation of teaching methods and the cultivation of innovative talents in colleges and puts forward corresponding countermeasures.
\end{abstract}

\section{Introduction}

Colleges are an important base for cultivating innovative talents. They are an important part of the national innovation system, and have an irreplaceable and important role in building an innovation oriented country[1-3]. China's colleges have carried out fruitful reforms on educational thinking, major settings, curriculum system, teaching content, and teaching material construction. Because of the lag in the reform of teaching methods, it directly influences the effectiveness of teaching reform. It is an important task for colleges to deepen the teaching reform, improve the quality of education and realize the scientific development of higher education in the new period by innovating teaching methods and cultivating students' innovative spirit and innovation ability[4].

\section{Innovation of Teaching Method is the Inevitable Requirement for Cultivating Innovative undertaking Talents}

Teaching method is an integral part of the whole teaching process, which has important influence on talent training[5-6]. Social development in the 21st century calls on cultivating innovative talents in colleges. The contradiction between the old teaching methods and modern teaching content is bound to affect the depth of teaching reform, and restrict the cultivation of innovative talents. Therefore, the reform of teaching methods is also the trend of reform of higher education in the world. Innovative teaching method is an objective requirement for building an innovation - oriented country. Building an innovation - oriented country is a major strategic decision that is related to the overall situation of China's modernization in the new century. American undergraduate education in the 1980s established the goal of cultivating innovative talents. Under the guidance of the idea that students are transformed into "explorers" from "recipients", the exploratory learning is valued and the problem-based learning model has got an unprecedented development in American research universities[7]. The "ability education" proposed by the British in the late 1970s was widely recognized by the British universities in the 1990s, and almost all universities have carried out active reform and exploration, and have achieved remarkable results[8-9]. 


\section{The Establishment of an Open and Diverse Teaching Method Innovation System}

Teaching methods are means, ways and tools used by teachers and students in common activities in order to complete a certain teaching tasks. Different educational ideas, different training objectives, different teaching contents, teachers with different personality, and students with different quality determine that the teaching methods should be diversified. Perfect lecture teaching is the basis, is the most ancient teaching method, and is currently the most common teaching method in colleges[10-11]. The advantage of the lecture teaching is that it takes less time, with low cost and high efficiency. Students can acquire systematic theory and a great deal of knowledge in a short time. History proves that the lecture teaching is an effective teaching method. The perfect lecture teaching method requires teachers to have deep basic knowledge, proficient in the development of the discipline, make preparations for lessons carefully, use the methods of question setting or questioning solving, such as comparison and classification, induction and deduction, analysis and synthesis, and the methods of theory connecting practice, adopt vivid language, and pay attention to student feedback. Open practice education is the focus, practice is the source of innovation, and practical ability is the important quality of innovative undertaking talents. To have a scientific and perfect training mechanism, as shown in fig. 1.

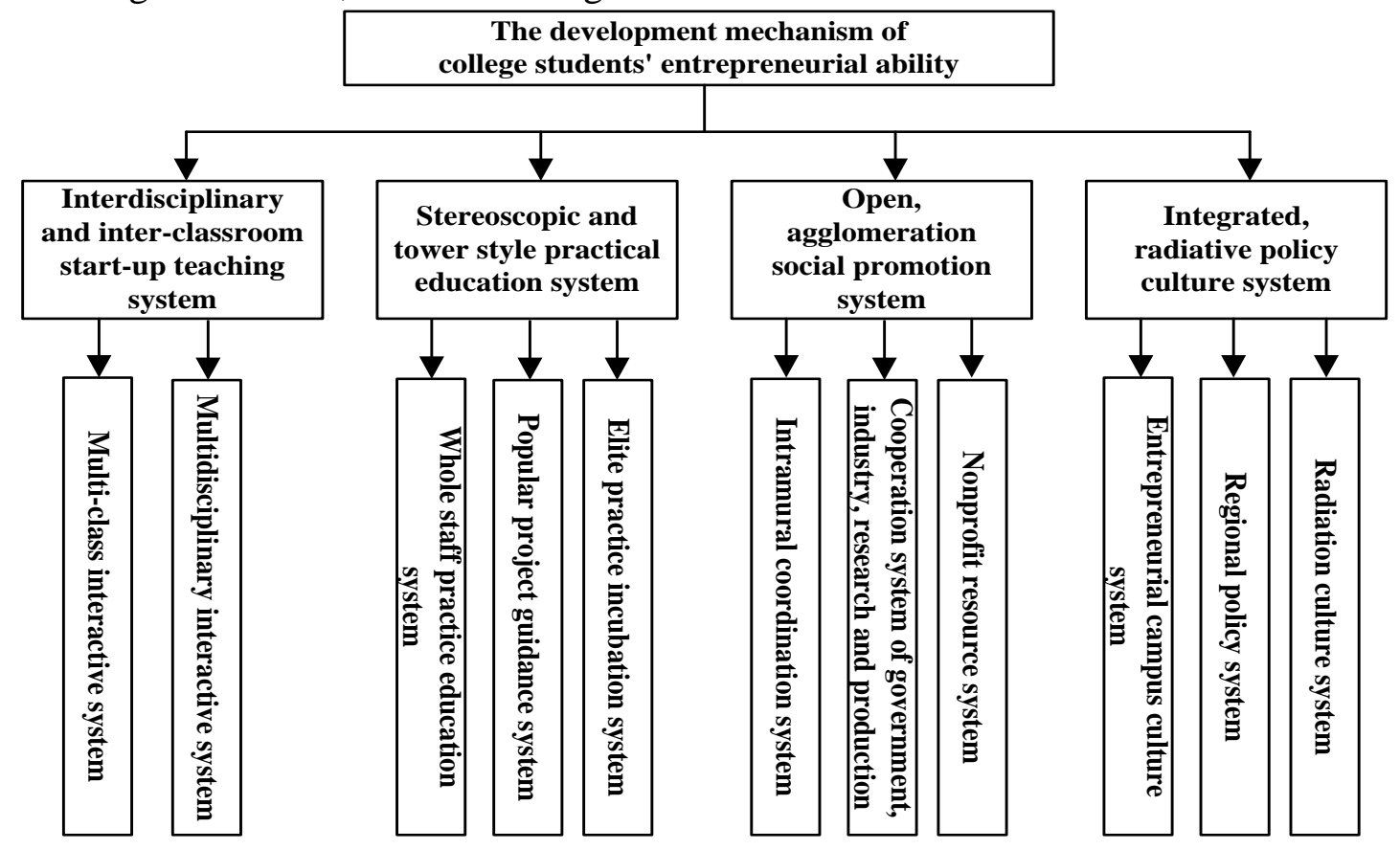

Figure1. Development mechanism architecture of Innovative entrepreneurial ability of "four in one" college student

Practical education refers to the exploratory activities applying the basic elements of practice into education and teaching which are carried out around the specific educational purpose, students experience and apply their knowledge in practice.

\section{Main Measures to Vigorously Promote the Innovation Undertaking of Teaching Method}

Lay Emphasis on University Teaching in ideology. Teaching and research is the university's two major responsibilities, and as the base of transmitting knowledge and cultivating talents, teaching should be the first priority of the university[12]. Education departments at all levels and colleges should attach great importance to university teaching, attach importance to the role of innovation of teaching methods on improving the quality of talents, carry out the discussion of reforming teaching methods, and develop relevant policies and measures to promote the innovation of teaching methods.

Change the Concept, and Firmly Establish the teaching concept of Focusing on "Students". One of the characteristics of teaching methods in colleges is that students are more independent in 
teaching activities. The second is that the teaching process in colleges and universities is a special process of students' learning and discovery, and must firmly establish the concept of focusing on "students".

Facing the Application, and cultivating the innovation consciousness and ability.Cultivating students' ability to analyze and solve problems independently and cultivating the applied talents are the fundamental goals in education. The training of strengthening students' innovative thinking ability is the key to cultivate students' creative consciousness and innovation ability, which includes training of students' imagination, the reverse thinking, the non-logical thinking, the three-dimensional thinking, the comprehensive thinking and so on. At present, the practical teaching contents which are facing to the application mainly include the curriculum design, the innovation practice projects of students' science and technology, teacher researching projects, and the design project in the organization of the electronic design games, which have a certain engineering practical value in the design practice projects.

The Promotion of Innovative and Enthusiastic Teaching Methods is Closely Related to the Cooperation of University Teachers. The use of teaching methods is the external manifestation of the intrinsic quality of university teachers. To promote the innovation of teaching methods, we must improve the teachers' sense of responsibility and ideological quality, change the teaching concept. In order to promote the innovation of teaching methods, teachers must also improve the teaching skills, and take the initiative to carry out the experiments and results summary of the teaching method reform. To establish a scientific innovation ability factor structure, as shown in fig. 2.

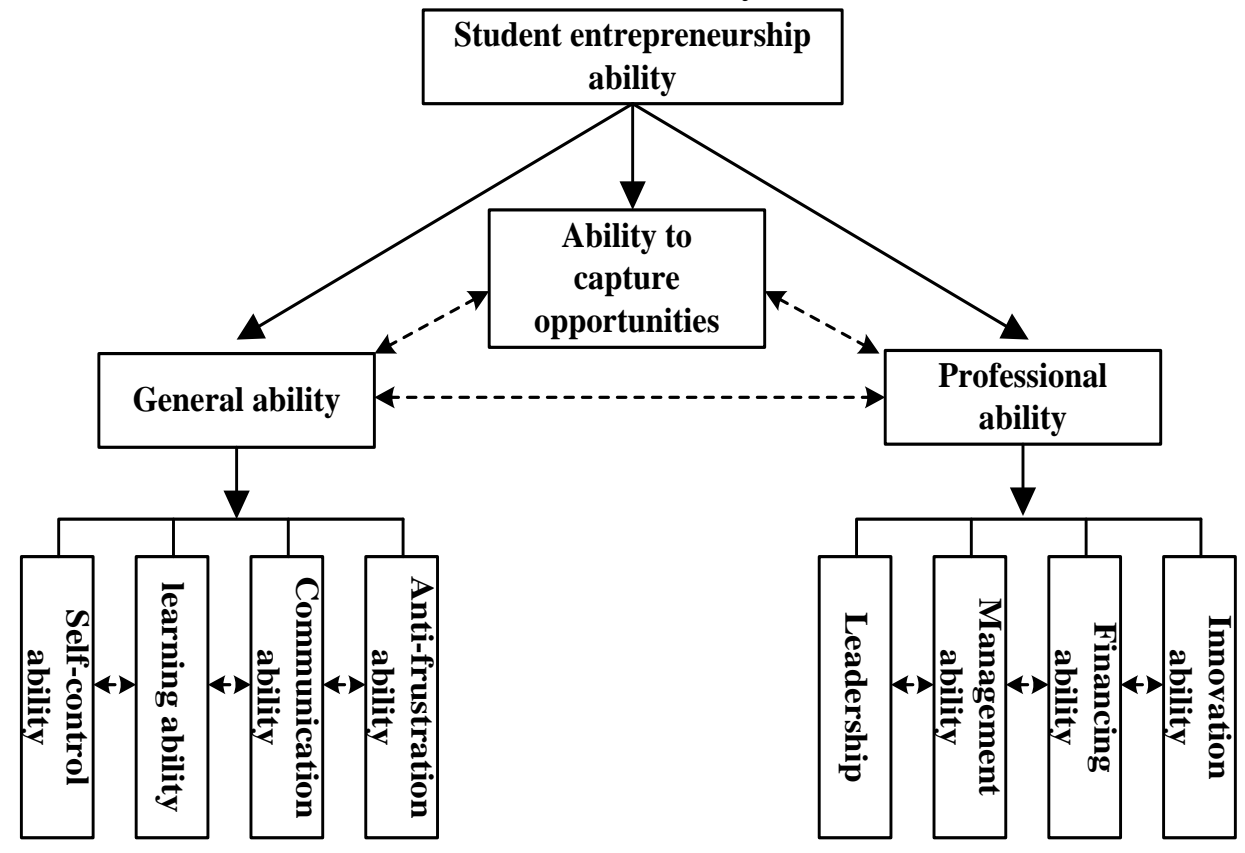

Figure 2. Innovative undertaking ability factor structure model of College students

Strengthen the Promotion and Application of the Achievements of Innovative Teaching Methods. Education departments and colleges should take effective measures, strengthen the publicity of innovative achievements, and carry out the training, research and promotion work of teaching methods, so that front-line teachers can benefit from the training and education of new teaching methods, which can expand the beneficiary groups of the innovation of teaching methods.

\section{Summary}

Higher education is an important base for cultivating innovative undertaking talents, and it is an important part of the national innovation system. It is an important task to deepen the teaching reform in the new period and improve the quality of education and realize the scientific development of higher education by innovating teaching methods and cultivating students' 
innovative spirit and innovative ability, and the innovation of teaching method is the inevitable requirement for cultivating innovative talents.

\section{Acknowledgments}

This research was financially supported by Key scientific research projects of Jiangxi Provincial Department of Education (Grant NO. GJJ161218). Nanchang institute of technology research start-up funding.

\section{References}

[1] Pan Maoyuan. Teaching Principles and Methods of Higher Education[M]. Beijing: People's Education Press, 2014: 176-185.

[2] Shi Jinghuan. Strengthening Practical Education: the Only Way to Cultivate Innovative Talents in Research Universities[J]. Tsinghua University Education Research, 2015, 26 (1): 5-9.

[3] Cui Dong, Guo Yongxin. Application on EDA simulation technology among the analog electronic technology teaching [J]. China Science and Technology Information .2013 (5): 208-209.

[4] Wang Ziting, Wu Rong and other people. EDA technology and application [M]. Lanzhou: Lanzhou University Press .2013.

[5] Zhao Hong. Research Teaching and the Reform of University Teaching Method[J]. Higher Education Research, 2013, 27 (2): 71-75.

[6] Y. Hu, M. M. Jovanovic. LED Driver with Self-Adaptive Drive Voltage. IEEE Transactions on Power Electronics, 2012, 23(6): 116-125

[7] Xiong Wei, Hou missionary and other people. Circuit design of Multisim 7and simulation application on Multisim 7 [M]. Beijing: Tsinghua University Press .2010.

[8] Y. K. Cheng, K. W. E. Cheng. General Study for Using LED to replace Traditional Lighting Devices. 2nd International Conference on Power Electronics Systems and Applications, Hong Kong, 2012.25(9):173-177

[9] Liu Baocun. Problem - based Learning Model in American Research Universities[J]. China Higher Education Research, 2014 (10): 60-62.

[10] Zhang Yantong. British Higher Education "Ability Education Declaration" and "Action Based Learning"[J]. Comparative Education Research, 2012 (1): 11-16.

[11] H. van der Broeck, G. Sauerlander, M. Wendt. Power Driver Topologies and Control Schemes for LEDs. IEEE Applied Power Electronics Conference, Anaheim, 2011, 31(5):319-325

[12]Zhu Qingshi. Taking value of innovative quality and cultivating successful innovative talents [J]. China Higher Education. 2012 (1): 81-84. 